\title{
STRATEGIC MANAGEMENT SYSTEM IN HIGHER EDUCATIONAL INSTITUTIONS AS A PROBLEM
}

\section{Rustam Shamuratov}

Researcher Of Tashkent State Pedagogical University, Uzbekistan

\section{ABSTRACT}

An efficient economy is, first and foremost, effective governance. The importance and application of the concepts of "management" and "management" in the modern world are close in content, but not exactly the same. Accordingly, the concept of "management" applies to all types of systems - technical, biological, socioeconomic and so on. The modern concept of "management" applies only to socio-economic systems, that is, organizational structures in which the obligatory element is the person and his goal-oriented activities. Thus, in modern times, the management of an organization or organizational structures is called "management".

KEYWORDS:- Higher education institutions, strategic management, system, problem, economics, management, management.

\section{INTRODUCTION}

Theories that differed in their approaches and content, as well as schools, significantly expanded their understanding of the possibilities of management and use as an independent field of knowledge. At present, the impact of management on all spheres of public life has grown significantly. Therefore, the principles, forms and methods of modern management are actively used in science, education, health, cultural institutions, and until recently it was difficult to imagine them. There is a growing recognition of the fact that management is a field of professionally trained people who have mastered the art of management. Therefore, the most important person in modern management is a person, his abilities, skills, knowledge and skills.

The main results and findings
The quality of management determines both the results of activities and the choice of ways and means to achieve them. a well-organized and well-coordinated team is needed to effectively address the challenges facing the organization, in which each member knows and carries out his work, works smoothly, without interruptions and solves most problems without conflicts, interested in the end result [4, p. 313].

The main task of management is to achieve the goals set before the organization at the lowest cost and in the shortest possible time. In solving this task, according to most authors, management theory and practice are based on four main functions. [2]:

- planning (setting goals of the organization);

- $\quad$ organization (optimal allocation of forces and resources);

motivation (striving for all members of the 
CURRENT RESEARCH JOURNAL OF PEDAGOGICS 2(9): 146-149,

September 2021 DOI: https://doi.org/10.37547/pedagogics-crjp-02-09-32

ISSN 2767-3278

(C)2021 Master Journals

\section{Crossref do) 8 Google}

Accepted 25 $5^{\text {th }}$ September, 2021 \& Published $30^{\text {th }}$ September, 2021

organization to work with maximum effort);

constant monitoring and correction of current work (focused on the implementation of the goals of the organization, a clear response to external and internal conditions).

Thus, most authors consider management to be an effective and efficient achievement of organizational goals through planning, organization, motivation, and control over organizational resources. These functions are interrelated and have two common features: they all require decision-making, and communication, information exchange is necessary for all of them in decision-making.

The core of the information management process is the basis for making management decisions [3]. These decisions can be made using a variety of ever-changing technologies [4. p. 39].

The evolution of the views of different schools on the management process of the organization is illustrated in Table 1.

Table 1

Basic schools of management

\begin{tabular}{|c|c|c|}
\hline School & Representatives & The uniqueness of the approach \\
\hline $\begin{array}{r}\text { Scien } \\
\text { manag }\end{array}$ & $\begin{array}{c}\text { G.Taylor, } \\
\text { F.Emerson and } \\
\text { L.Gilbrett, G.Gantt, } \\
\text { G.Ford and others }\end{array}$ & $\begin{array}{l}\text { Representatives of the School of Scientific } \\
\text { Management tried to rationalize the work of } \\
\text { individual workers through standardization } \\
\text { and standardization, and focused their } \\
\text { attention on the level of the workshop. }\end{array}$ \\
\hline $\begin{array}{r}\mathrm{Admi} \\
\text { man }\end{array}$ & $\begin{array}{l}\text { A. Fayol, L.Urvik, } \\
\text { Dj.Muni, E.Reyli, } \\
\text { L.Gyulik, } \\
\text { U.Nyumen, E.Allen, } \\
\text { M.Weber and } \\
\text { others }\end{array}$ & $\begin{array}{l}\text { Proponents of the administrative school } \\
\text { approach the problem of managing an } \\
\text { organization in general by focusing on the } \\
\text { following points: } \\
\text { - grouping of works into sectors, sectors into } \\
\text { divisions and larger divisions; } \\
\text { - distribution of powers; } \\
\text { - determination of responsibility for }\end{array}$ \\
\hline $\begin{array}{l}\text { school of human } \\
\text { relations and } \\
\text { behavioral science } \\
\text { (neoclassical school) }\end{array}$ & \begin{tabular}{|} 
G.Myunsterberg, \\
E.Meyo, \\
F.Rotlisberger, M. \\
Follet. Ch. Barnard, \\
A. Maslou, R. \\
Laykert, D. \\
McGregor, F. \\
Gertsberg, K. \\
Ardjiris et al
\end{tabular} & $\begin{array}{l}\text { The main contribution of the concept of } \\
\text { human relations to the development of } \\
\text { management is the proof that it is possible to } \\
\text { significantly increase labor productivity by } \\
\text { creating a favorable socio-psychological } \\
\text { climate in the workplace. Later, the concept of } \\
\text { human relations is supplemented by the } \\
\text { concept of behavior, which deals with power } \\
\text { and prestige, motivation, leadership and other } \\
\text { similar aspects of management. }\end{array}$ \\
\hline
\end{tabular}




\begin{tabular}{|c|c|c|}
\hline $\begin{array}{l}\text { Quantitative school } \\
\text { since the } 1950 \\
\text { (management } \\
\text { science)) }\end{array}$ & $\begin{array}{l}\text { R. Akoff, L. von } \\
\text { Bertalanfi, S .; One, } \\
\text { A. Goldberger, D. } \\
\text { Fosrester, R. Lyus, } \\
\text { L. Klein et al. }\end{array}$ & $\begin{array}{l}\text { The quantitative approach to management } \\
\text { relies on the use of statistical methods, } \\
\text { optimization models, information models, and } \\
\text { computer modeling methods, in connection } \\
\text { with which many quality solutions are replaced } \\
\text { by quantitative solutions. } \\
\text { The quantitative approach to management is } \\
\text { based on the use of statistical methods, } \\
\text { optimization models, information models and }\end{array}$ \\
\hline
\end{tabular}

Each school has made a significant contribution to the science of management, but despite the diversity of views, it is possible to distinguish three main approaches - process, systemic and situational approaches [5] (Table 2).

Table 2

Basic approaches in management

\begin{tabular}{|c|c|c|c|}
\hline Approach & Uniqueness & Superiority & Disadvantage \\
\hline Processed & $\begin{array}{c}\text { Management is seen as } \\
\text { a process }\end{array}$ & $\begin{array}{l}\text { Within management, it is } \\
\text { traditionally seen as a } \\
\text { series of continuous, } \\
\text { interconnected actions that } \\
\text { demonstrate the functions } \\
\text { of management, in which } \\
\text { planning, motivation, } \\
\text { organization, and control } \\
\text { are separated. }\end{array}$ & $\begin{array}{l}\text { It does not reflect the } \\
\text { interrelationships of all } \\
\text { the internal } \\
\text { components of the } \\
\text { organization and the } \\
\text { relationship with the } \\
\text { external environment, } \\
\text { that is, there is no } \\
\text { system in the } \\
\text { management process }\end{array}$ \\
\hline Systematic & $\begin{array}{c}\text { An integrated } \\
\text { approach to the } \\
\text { organization's } \\
\text { activities, taking into } \\
\text { account the combined } \\
\text { influence of external } \\
\text { and internal factors }\end{array}$ & $\begin{array}{l}\text { Represents the } \\
\text { organization as a unit of its } \\
\text { founders }\end{array}$ & $\begin{array}{l}\text { It does not identify key } \\
\text { variables that affect } \\
\text { governance }\end{array}$ \\
\hline Conditional & $\begin{array}{l}\text { Denies any universal } \\
\text { methods of } \\
\text { management and is } \\
\text { based on the } \\
\text { application of specific } \\
\text { management actions in } \\
\text { specific situations }\end{array}$ & $\begin{array}{l}\text { Provides interconnected } \\
\text { features of the situation }\end{array}$ & $\begin{array}{c}\text { Universal management } \\
\text { supports are not } \\
\text { available, not fully } \\
\text { justified }\end{array}$ \\
\hline
\end{tabular}


CURRENT RESEARCH JOURNAL OF PEDAGOGICS 2(9): 146-149,

September 2021 DOI: https://doi.org/10.37547/pedagogics-crjp-02-09-32

ISSN 2767-3278

(C)2021 Master Journals

Crossref do: 81 Google

Accepted 25th September, 2021 \& Published 30 ${ }^{\text {th }}$ September, 2021

Although the situational approach is now the leading one, the dissertation argues that the most preferred is the systemic approach, as it seeks to focus not only on the internal affairs of the organization but also on long-term changes in the environment. the strategy to be developed should also be put in place. In the context of the command-and-control system of the economy, many organizations could operate successfully, focusing their attention mainly on the internal problems associated with increasing the efficiency of resource use in current activities. In the conditions of transition to market relations, the stability of the education system is undermined by external influences, and it is no longer possible to return to the status quo [6. p. 293]. Therefore, the importance of strategic management, which allows to operate in a competitive environment in the long run, has increased dramatically in recent decades.

\section{Conclusion}

The term "strategic management" was coined in the 60s and 70s of the last century, when it began to be used to distinguish between current management at the production level and management at the highest level. A leading idea that reflects the essence of the transition from operational management to strategic management is to focus the attention of top management around themselves in order to respond to changes in the organization in a timely manner. Development of strategic management ideas Frankenhofs and Granger (1971), Ansoff (1972), Schendel and Hatten (1972), Irwin (1974), L.G. Zeitsev, M.I. Sokolov, O.S, Vixanskiy, V.R. Vesnin, A.L. Gaonenko, A.P. It is reflected in the scientific work of Pankrukhin and others.

\section{RefERENCES}

1. Mescon M.H, Albert M., Hedouri F. Fundamentals of management: Trans. from English M.: "Delo", 1992. - 702 p.

2. Daft R.L. Management. - SPb: Peter, 2002 $832 \mathrm{p}$.

3. Peter Drucker, Management: Tasks, Responsibilities, Practices, New York: Harper \& Row, 1973.

4. Lambrin Jean-Jacques. Market oriented management / Transl. From English. ed. V.B. Kolchanov. - SPb: Peter, 2007 - 800 p.

5. Fundamentals of management: electronic training course / L.V. Plekhova, T.M. Anurina, S.A. Legkostaev et al. - electron, dan. - M.: KNORUS, 2008. - 1.electronic opt. disk: stars .., color.

6. Reznik S.D. Department management: Textbook. 2-nd ed., Revised and enlarged. M.: INFRA-M, 2005. - 635 p.

7. Vikhansky O.S. Strategic management: Textbook. - 2nd ed., Rev. and add. - M.: Economist, 2003 - 296 p. 